\title{
Peran Lembaga Kesejahteraan Sosial (LKS) Rumah Harapan Mulya dalam Membentuk Keluarga Sakinah para Tunagrahita
}

\author{
Siti Qomariah \\ Institut Agama Islam Sunan Giri Ponorogo \\ sitiqomari@gmail.com
}

\begin{abstract}
Abstrak
Desa merupakan unit pemerintahan terkecil yang mewujudkan pembangunan melalui pemberdayaan yang memiliki konsep dan tahapan yang bertujuan untuk kesejahteraan masyarakat. Dalam mewujudkan kesejahteraan masyarakat dapat dimulai dari komponen terkecil yaitu keluarga. Dalam kehidupan berkeluarga terdapat setiap fungsi dan tanggung jawab setiap anggota keluarga untuk mencapai kehidupan yang harmonis. Keluarga memiliki karakteristik yang berbeda-beda dengan perjalanan kehidupan yang berbeda pula. Maka dari itu penelitian ini membahas tentang fenomena yang ada di Dusun Tanggungrejo Desa Karangpatihan Kecamatan Balong Kabupaten Ponorogo tentang masyarakat tunagrahita yang diberdayakan melalui Lembaga Kesejahteraan Sosial (LKS) Rumah Harapan Mulya. Pemberdayaan ini memiliki peran dalam membentuk keluarga sakinah para tunagrahita. Penelitian yang dilakukan adalah penelitian kualitatif dengan memperhatikan teori Fungsinalisme Struktural oleh Talcott Parson yang menganalogikan bahwa masyarakat seperti halnya makhuk hidup yang terus tumbuh dan melihat empat fungsi imperatif AGIL dalam menganalisis tatanan sosial. Lembaga Kesejahteraan Sosial (LKS) Rumah Harapan Mulya di Dusun Tanggungrejo Desa Karangpatihan Kecamatan Balong Kabupaten Ponorogo merupakan tempat pemberdayaan masyarakat tunagrahita dan masyarakat miskin. Kegiatan yang dilakukan melalui Lembaga Kesejahteraan Sosial (LKS) Rumah Harapan Mulya adalah pemberdayaan di bidang keterampilan dan bidang peternakan. Masyarakat tunagrahita merupakan masyarakat yang memiliki keterbatasan intelektual yang menyebabkan mereka berada pada kondisi dibawah normal. Masyarakat tunagrahita yang ada di Lembaga Kesejahteraan Sosial (LKS) Rumah Harapan Mulya merupakan tunagrahita dengan kategori ringan dan sedang. Keluarga tunagrahita dapat memenuhi kebutuhan pokok anggota keluarga dengan penghasilan dari pemberdayaan di Lembaga Kesejahteraan Sosial (LKS) Rumah Harapan Mulya. Keluarga sakinah para tunagrahita dapat terwujud melalui pembinaan dari Lembaga Kesejahteraan Sosial (LKS) Rumah Harapan Mulya.

Kata Kunci: Peran, Lembaga Kesejahteraan Sosial, Keluarga sakinah

\section{Abstract}

The village is the smallest government unit that realizes development through empowerment which has concepts and stages aimed at the welfare of the community. In realizing the welfare of society, it can be started from the smallest component, namely the family. In family life there are every function and responsibility of each family member to achieve a harmonious life. Families have different characteristics with different life journeys. Therefore, this study discusses the phenomena that exist in the Hamlet of Responsibilities, Karangpatihan Village, Balong District, Ponorogo Regency about the mentally retarded community who are empowered through the Social Welfare Institution (LKS) Rumah Harapan Mulya. This empowerment has a role in forming a sakinah family for the mentally retarded. This research is a qualitative research by paying attention to the theory of Structural Functionalism by Talcott Parson which makes an analogy that society is like a living being that continues to grow and sees the four imperative functions of AGIL in analyzing
\end{abstract}


social order. The Social Welfare Institution (LKS) Rumah Harapan Mulya in the Hamlet of Responsibilities, Karangpatihan Village, Balong District, Ponorogo Regency is a place for empowering mentally retarded and poor communities. Activities carried out through the Social Welfare Institution (LKS) Rumah Harapan Mulya are empowerment in the field of skills and the field of animal husbandry. The mentally retarded community is a society that has intellectual limitations that cause them to be in a below normal condition. The mentally retarded community in the Rumah Harapan Mulya Social Welfare Institution (LKS) is mentally retarded with mild and moderate categories. Mentally retarded families can meet the basic needs of family members with income from empowerment at the Rumah Harapan Mulya Social Welfare Institution (LKS). The sakinah family of the mentally retarded can be realized through guidance from the Rumah Harapan Mulya Social Welfare Institution (LKS).

Keywords: Role, Social Welfare Institution, Sakinah Family

\section{PENDAHULUAN}

Desa menjadi pusat kehidupan masyarakat golongan menengah kebawah yang membutuhkan peran serta keterlibatan Pemerintah Desa dalam mendukung, mengatur dan menciptakan kondisi perekonomian yang stabil dalam memenuhi kebutuhan masyarakat desa. Program pemerintah dapat berjalan jika ada peran yang aktif dari masyarakat. Pemberdayaan masyarakat desa harus beriringan dengan peran penuh dari pemerintah (Maikowati : 2019). Kegiatan pemberdayaan masyarakat diharapkan dapat mengangkat kehidupan masyarakat menjadi lebih sejahtera, dan mempunyai kekuatan dalam memenuhi kebutuhan hidup yang utama, dan pada akhirnya akan menciptakan kemandirian dalam masyarakat. Tentunya kemandirian yang dimaksud tidak hanya dari aspek ekonomi saja, tetapi juga secara sosial, budaya, hak bersuara atau berpendapat, bahkan sampai pada kemandirian masyarakat dalam menentukan hak-hak politiknya(Hamid : 2018).

Pemberdayaan merupakan sebuah proses yang memiliki konsep dan tahapan yang bermakna dalam masyarakat. Pemberdayaan berbasis partisipatif merupakan salah satu pendekatan yang meletakkan landasan pembangunan yang tumbuh dan berkembang dari masyarakat, diselenggarakan secara sadar dan mandiri oleh masyarakat dan hasilnya dinikmati oleh seluruh masyarakat (Zubaer : 2016). Masyarakat sebagai subyek dapat melakukan tindakan secara kolektif mengembangkan potensi, kreasi, memperkuat posisi dan meraih kedaulatan. Namun, jika masyarakat tersebut merupakan orang-orang berkebutuhan khusus seperti masyarakat tunagrahita, akan sulit dalam menentukan arah dan tujuan hidupnya. Masyarakat tunagrahita cenderung berperilaku pasif dalam kehidupan sosialnya, dan banyak masyarakat yang menjauhi mereka. Padahal mereka juga merupakan bagian dari struktur masyarakat tersebut. Jika masyarakat tersebut terpecah, maka bisa dikatakan desa tersebut tidak mampu dalam hal manajemen perilaku sosial seluruh masyarakatnya. 
Dalam memahami masalah masyarakat memang tidak mudah. Butuh keahlian dalam proses pendampingan masyarakat. Masyarakat dapat bekerja secara mandiri jika diarahkan kepada pengembangan kapasitas. Pemberdayaan yang dilakukan kepada masyarakat tunagrahita dimulai dengan strategi khusus yang tepat sasaran. Dengan keadaan dan karakteristik tunagrahita yang memiliki keterbatasan, maka tindakan mereka hanyalah menjadi pelaku konsumtif tanpa memiliki inisiatif dalam menentukan perubahan dan perkembangan ekonomi keluarga mereka. Mereka hanya tahu bagaimana cara menggunakan bantuan pemerintah tanpa memiliki arah dan tujuan dalam mengelola ekonomi keluarga. Namun, Pemerintah Desa Karangpatihan beserta pelaku pemberdayaan berinisiatif dalam memperhatikan kehidupan masyarakat tunagrahita agar menjadi masyarakat yang memiliki kekuatan ekonomi yang mandiri. Melalui sebuah tempat yang bernama Lembaga Kesejahteraan Sosial (LKS) Rumah Harapan Mulya, para pengurus mulai melakukan pemberdayaan khusus untuk masyarakat tunagrahita. Masyarakat tunagrahita juga memiliki hak kehidupan yang sama seperti pada masyarakat lainnya, yang berbeda adalah kondisi keterbatasan yang dimiliki tunagrahita. Disamping itu, masyarakat tunagrahita juga memiliki sebuah keluarga yang dibina melalui Lembaga Kesejahteraan Sosial (LKS) Rumah Harapan Mulya. Lembaga ini merupakan tempat yang dirintis dan dikelola atas dasar swadaya masyarakat sekitar di Dukuh Tanggungrejo Desa Karangpatihan.

Penelitian ini dilakukan untuk mengetahui profil dan kegiatan di Lembaga Kesejahteraan Sosial (LKS) Rumah Harapan Mulya. Penelitian ini dimaksudkan untuk mengetahui kondisi objektif masyarakat tunagrahita yang diberdayakan di Lembaga Kesejahteraan Sosial (LKS) Rumah Harapan Mulya. Dan penelitian ini bertujuan untuk menganalisis peran Lembaga Kesejahteraan Sosial (LKS) Rumah Harapan Mulya dalam membentuk keluarga sakinah para tunagrahita.

Dalam sebuah masyarakat terdapat unit terkecil yang sangat berperan dalam membentuk karakter seseorang yaitu sebuah keluarga. Pengertian keluarga memiliki dua dimensi. Yang pertama, keluarga diartikan sebagai ikatan kekerabatan antar individu. Pernyataan ini merujuk kepada mereka yang mempunyai hubungan darah dan pernikahan. Yang kedua, keluarga yang bersinonim "rumah tangga" dalam makna ini ikatan kekerabatan amat penting, namun yang ditekankan adalah adanya kesatuhunian dan ekonomi (Umar : 2014). Sedangkan hidup berkeluarga adalah kehidupan bersama dua orang lawan jenis yang bukan muhrimnya yang telah mengikatkan diri dengan tali perkawinan beserta anak keturunannya yang dihasilkan dari akibat perkawinan tersebut.

Islam menginginkan pasangan suami istri yang telah membina suatu rumah tangga bersifat langgeng. Terjalin keharmonisan diantara suami istri yang saling mengasihi dan menyayangi itu sehingga masing-masing pihak merasa damai dalam rumah tangganya. Rumah tangga seperti inilah yang diinginkan Islam, yakni rumah tangga sakinah. Namun 
demikian, upaya membentuk keluarga sakinah jelas tidaklah semudah membalik telapak tangan. Di dalam keluarga sakinah ketenangan hati mudah ditemui, ketentraman dapat terjaga, dan masing-masing elemen keluarga saling melengkapi dalam mengupayakan kebaikan dalam keluarganya. Kehidupan keluarga yang saling mendukung dan melindungi menjadi faktor penentu keharmonisan keluarga yang bersangkutan. Keluarga yang di dalamnya anggota keluarganya tidak saling mendukung, maka kehidupan keluarga tersebut akan bermasalah dari hari ke hari (Supriyono : 2015).

Masyarakat tunagrahita juga memiliki sebuah keluarga yang harus dibina untuk mencapai keharmonisan. Dalam membentuk keluarga sakinah para tunagrahita dapat dilakukan dengan melalui pemberdayaan ekonomi dan sosial masyarakat. Perlunya perhatian khusus dalam mengarahkan seluruh keluarga tunagrahita dalam menjalani kehidupan rumah tangga yang mencapai keluarga sakinah. Pemberdayan dapat dilakukan melalui pemberdayaan ekonomi dengan melatih para tunagrahita untuk membatik, membuat keset, dan berbagai kerajinan lainnya serta mengelola peternakan. Pemberdayaan tunagrahita merupakan kegiatan yang sangat menarik dengan perhatian yang khusus dalam interaksi lisan maupun fisik.

Pemberdayaan masyarakat tunagrahita di Lembaga Kesejahteraan Sosial (LKS) Rumah Harapan Mulya dapat dianalisis dengan menggunakan teori Fungsional struktural oleh Talcott Parsons. Dalam teorinya, Parsons menganalogikan perubahan sosial pada masyarakat seperti halnya pertumbuhan pada mahkluk hidup. Parsons berpendapat bahwa setiap masyarakat tersusun dari sekumpulan subsistem yang berbeda berdasarkan strukturnya maupun berdasarkan makna fungsionalnya bagi masyarakat yang lebih luas. Ketika masyarakat berubah, umumnya masyarakat tersebut akan tumbuh dengan kemampuan yang lebih baik untuk menanggulangi permasalahan hidupnya.

Dalam perspektif fungsionalisme ada beberapa persyaratan atau kebutuhan fungsional yang harus dipenuhi agar sebuah sistem sosial bisa bertahan. Parsons kemudian mengembangkan apa yang dikenal sebagai imperatif-imperatif fungsional agar sebuah sistem bisa bertahan. Imperatif-imperatif tersebut adalah Adaptasi, Pencapaian Tujuan, Integrasi, dan Latensi atau yang biasa disingkat AGIL (Adaptation, Goal attainment, Integration, Latency) (Rozak: 2017). Berikut adalah penjelasan tentang empat fungsi imperatif AGIL:

1. Adaptasi, sebuah sistem ibarat makhluk hidup, artinya agar dapat terus berlangsung hidup, sistem harus dapat menyesuaikan diri dengan lingkungan yang ada. Harus mampu bertahan ketika situasi eksternal sedang tidak mendukung.

2. Goal (Pencapaian), sebuah sistem harus memiliki suatu arah yang jelas dapat berusaha mencapai tujuan utamanya. Dalam syarat ini, sistem harus dapat mengatur, menentukan dan memiliki sumberdaya untuk menetapkan dan mencapai tujuan yang bersifat kolektif. 
3. Integrasi, sebuah sistem harus mengatur hubungan antar bagian yang menjadi komponennya. Sistem juga harus dapat mengelola hubungan antara ketiga fungsi penting lainnya.

4. Latensi, Pemeliharaan pola, sebuah sistem harus melengkapi, memelihara dan memperbaiki pola-pola kultural yang menciptakan dan menopang motivasi.

Teori struktural fungsional mengansumsikan bahwa masyarakat merupakan sebuah sistem yang terdiri dari berbagai bagian atau subsistem yang saling berhubungan. Bagianbagian tersebut berfungsi dalam segala kegiatan yang dapat meningkatkan kelangsungan hidup dari sistem. Fokus utama dari berbagai pemikir teori fungsionalisme adalah untuk mendefinisikan kegiatan yang dibutuhkan untuk menjaga kelangsungan hidup sistem sosial. Terdapat beberapa bagian dari sistem sosial yang perlu dijadikan fokus perhatian, antara lain ; faktor individu, proses sosialisasi, sistem ekonomi,pembagian kerja dan nilai atau norma yang berlaku.

\section{METODE PENELITIAN}

Jenis penelitian yang digunakan adalah studi kasus atau penelitian lapangan (field research). Peneliti menggali suatu fenomena tertentu (kasus) dalam suatu waktu dan kegiatan serta mengumpulkan informasi secara mendalam dengan menggunakan berbagai prosedur pengumpulan data selama periode tertentu untuk memperoleh informasi dalam suatu penelitian (Wahyuningsih : 2013). Maka pendekatan penelitian yang digunakan yaitu pendekatan kualitatif yang bertujuan memahami fenomena yang dialami oleh subyek penelitian (Syahrum : 2015). Teknik analisis yang digunakan dalam penelitian ini dengan menggunakan metode induktif yang berangkat dari kasus-kasus bersifat khusus berdasarkan pengalaman nyata (ucapan atau perilaku subyek penelitian atau situasi lapangan penelitian) untuk kemudian kita rumuskan menjadi model, konsep, teori, prinsip, proposisi, atau definisi yang bersifat umum (Nugraheni : 2014). Dalam penelitian ini penulis berangkat dari fenomena masyarakat tunagrahita yang terjadi di Dusun Tanggungrejo Desa Karangpatihan Kecamatan Balong Kabupaten Ponorogo. Penulis tertarik untuk meneliti peran Lembaga Kesejahteraan Sosial (LKS) Rumah Harapan Mulya dalam membentuk keluarga sakinah para tunagrahita.

Dari informasi dan data yang telah dikumpulkan, maka akan dianalisis dengan pendekatan Thick Description oleh Clifford Greetz yang mendeskripsikan data secara mendalam menjadi bahan pembahasan dari penelitian ini (Greetz : 1973). Maka informasi dan data tersebut harus dipecah menjadi komponen-komponen yang lebih rinci sesuai dengan jenis dan pokok pembahasan yang diambil peneliti dalam menganalisis data dan informasi mengenai peran Lembaga Kesejahteraan Sosial (LKS) Rumah Harapan Mulya dalam membentuk keluarga sakinah para tunagrahita. 


\section{HASIL PEMBAHASAN}

\section{Lembaga Kesejahteraan Sosial (LKS) Rumah Harapan Mulya}

Ketika membahas mengenai kemiskinan yang terjadi di seluruh Indonesia, dan khususnya di Kabupaten Ponorogo, maka yang terlintas adalah fenomena kemiskinan yang dialami oleh warga Dukuh Tanggungrejo Desa Karangpatihan Kecamatan Balong Kabupaten Ponorogo, khususnya warga memiliki keterbelakangan yang disebut sebagai tunagrahita. Pemerintah setempat harus memiliki strategi khusus dalam mendukung perkembangan dan kemajuan perekonomian warga miskin dan khususnya warga yang memiliki keterbelakangan. Untuk itu, di Desa Karangpatihan ini memiliki program dan upaya dalam pengembangan ekonomi secara merata untuk seluruh masyarakatnya.

Pada awalnya, Rumah Harapan berdiri sebagai Kelompok Swadaya Masyarakat (KSM) yang dirintis oleh Bapak Eko Mulyadi yang sekarang menjabat sebagai Kepala Desa Karangpatihan. Dan berjalannya waktu, pengurus Rumah Harapan menjadi sistematis, sehingga Bapak Eko Hanya menjadi pendamping secara umum. Segala bentuk kegiatan telah dirancang dan dilaksanakan secara berkelanjutan dan dengan beberapa inovasi yang membuat program pemberdayaan di Rumah Harapan ini semakin baik dan berkembang hingga saat ini yang berdiri sebagai Lembaga Kesejahteraan Sosial (LKS) Rumah Harapan Mulya. Pada tanggal 9 Januari 2020 "Kelompok Swadaya Masyarakat (KSM) Rumah Harapan" berganti nama perkumpulan menjadi "Lembaga Kesejahteraan Sosial (LKS) Rumah Harapan Mulya" yang didirikan oleh Ibu Yuliana beserta rekannya Bapak Dedik Irawan dan Ibu Sumarsih. Tempat perkumpulan ini berada di Jalan Arjuna, Dukuh Tanggungrejo, RT 005 / RW 001, Desa Karangpatihan, Kecamatan Balong, Kabupaten Ponorogo.

Suatu perkumpulan atau organisasi didirikan oleh beberapa pihak dengan memperhatikan kebutuhan yang diperlukan dalam pelaksanaan program yang telah direncanakan sebelumnya. Sesuai dengan yang tercantum di dalam Akta Pendirian Perkumpulan Lembaga Kesejahteraan Sosial Rumah Harapan No. 08 Tahun 2020 perlu diketahui bahwa, Lembaga Kesejahteraan Sosial (LKS) Rumah Harapan Mulya merupakan sebuah perkumpulan yang didirikan atas dasar swadaya masyarakat dengan modal yang bersumber dari iuran anggota, bantuan dari Pemerintah maupun Swasta berupa uang maupun barang yang sifatnya tidak mengikat, dana atau hibah dari dalam dan luar negri dan sumber pendapatan lainnya yang tidak bertentangan dengan peraturan perundangundangan.

Pendirian Lembaga Kesejahteraan Sosial (LKS) Rumah Harapan Mulya ini memiliki maksud dan tujuan di bidang sosial, keagamaan dan kemanusiaan. Usaha-usaha yang dilakukan Lembaga Kesejahteraan Sosia (LKS) Rumah Harapan Mulya yaitu elakukan pembinaan, pelatihan, pendampingan, dan pemberdayaan bagi penyandang disabilitas, masyarakat miskin, janda, lansia, anak yatim piatu dan remaja dalam rangka mewujudkan masyarakat yang adil, makmur dan sejahtera. 
Lembaga Kesejahteraan Sosial (LKS) Rumah Harapan Mulya merupakan sebuah nama perkumpulan yang memiliki visi dan misi yang disimbolkan dengan Bahasa Jawa yaitu “ Urip Iku Urup" yang jika diterjemahkan dalam Bahasa Indonesia menjadi "Hidup Itu Nyala”. Dari kalimat tersebut mengandung arti penjelasan bahwasannya, hidup itu hendaknya dapat memberi manfaat kepada orang lain di sekitar kita, semakin besar manfaat yang kita berikan tentu akan semakin baik untuk kita dan orang lain, tetapi sekecil apapun manfaat yang kita berikan kepada orang lain jangan sampai kita meresahkan masyarakat.

Adanya Lembaga Kesejahteraan Sosial (LKS) merupakan sebuah inisiatif dari pihak penyelenggara yang selanjutnya bisa disebut sebagai pekerja sosial. Pekerja sosial memiliki peran penting dalam pemberdayaan masyarakat. Pekerja sosial selalu memperhatikan masyarakat miskin dengan memusatkan kepada pemberdayaan masyarakat miskin, misalnya dengan pelatihan atau program keterampilan atau keahlian dan meningkatkan taraf hidup masyarakat, seperti dibukanya akses lapangan pekerjaan. Ketika masyarakat mendapatkan pekerjaan, maka akan memiliki penghasilan dan bisa memenuhi kebutuhan pokok dengan makanan dan minuman yang sehat dan bergizi (Raharjo :2015). Organisasi masyarakat yang dibentuk tersebut disebut lembaga kesejahteraan sosial (disingkat LKS) seperti tercantum dalam Undang-Undang No. 11/2009. Dalam UU tersebut dikemukakan bahwa masyarakat dapat berpartisipasi melalui berbagai bentuk wadah, salah satunya adalah melalui LKS (Sitepu:2011).

Setelah diamati, Lembaga Kesejahteraan Sosial (LKS) Rumah Harapan Mulya terdapat banyak sekali kegiatan yang telah direncanakan dan telah direalisasikan. Sesuai dengan usaha-usaha yang hendak diselenggarakan di Lembaga Kesejahteraan Sosial (LKS) Rumah Harapan Mulya, maka terdapat beberapa kegiatan yang dijalankan mulai dari pemberian bantuan hingga pelatihan keterampilan yang akan menjadi usaha pemandirian perekonomian warga miskin. Lembaga Kesejahteraan Sosial (LKS) Rumah Harapan Mulya menjadi tempat yang memulai kegiatan pemberdayaan bagi masyarakat tuangrahita dan masyarakat miskin. Bentuk kegiatan pemberdayaan di Lembaga Kesejahteraan Sosial (LKS) Rumah Harapan Mulya di bidang kerajinan dan bidang peternakan. Dalam bidang keterampilan, para tunagrahita dibina dan dilatih untuk membuat kerajinan batik ciprat, membuat keset dari kain perca, dan kerajinan lainnya yang lebih sederhana dalam pembuatannya. Sedangkan dalam bidang peternakan, para tunarahita di beri bibit dan dibina untuk merawat hewan ternak seperti ayam, ikan lele dan kambing di rumah mereka. Masyarakat tunagrahita juga dibina dalam hal menjalani dan mengatur kehidupannya sehari-hari. Terbentuknya keluarga dari para tunagrahita tak terlepas dari campur tangan para pengurus Lembaga Kesejahteraan Sosial (LKS) Rumah Harapan Mulya dan masyarakat sekitar.

Kegiatan pemberdayaan tunagrahita dikemas dengan sangat baik, konsisten dan mampu menopang perekonomian keluarga. Dengan bentuk usaha dan kegiatan yang telah diselenggarakan di Lembaga Kesejahteraan Sosial (LKS) Rumah Harapan Mulya, maka 
tujuan dari pemberdayaan dapat tercapai sesuai harapan bersama. Namun diluar dari aktivitas pemberdayaan ekonomi. Lembaga Kesejahteraan Sosial (LKS) Rumah Harapan Mulya juga melakukan pembinaan bagi masyarakat tunagrahita khususnya dalam menjalani kehidupannya sehari-hari di dalam keluarga dan kehidupan sosial bermasyarakat.

\section{Kondisi Objektif Masyarakat Tunagrahita di Lembaga Kesejahteraan Sosial (LKS) Rumah Harapan Mulya}

Kampung Idiot menjadi gelar dari Desa Karangpatihan Kecamatan Balong Kabupaten Ponorogo yang diberikan oleh masyarakat sekitarnya karena desa tersebut ditempati oleh masyarakat yang memiliki tingkat keterbelakangan mental yang cukup tinggi. Kondisi tersebut dialami sebagian besar warga yang tinggal diujung barat Desa Karangpatihan, yaitu di Dusun Tanggungrejo. Kondisi yang dialami sebagian besar masyarakat tersebut sudah terjadi secara turun temurun (Listiyani; 2016). Fenomena tunagrahita merupakan fenomena cacat mental yang menjadi satu dari beberapa fenomena penyimpangan dalam diri manusia di dunia ini. Kondisi yang dialami tunagrahita sangat beragam. Seperti tunagrahita di Dusun Tanggungrejo Desa Karangpatihan ini dibagi menjadi 3 golongan, yaitu: tunagrahita ringan, tunagrahita sedang dan tunagrahita berat.

Tunagrahita dapat dibedakan menjadi tiga kelompok diantaranya yaitu:

1. Tunagrahita ringan, yaitu tunagrahita dengan kondisi fisik yang tidak berbeda dengan orang normal pada umumnya, mereka mempunyai IQ antara 50 sampai dengan 70. Mereka termasuk kelompok yang mampu dididik, mereka masih bisa diajarkan membaca, menulis dan berhitung.

2. Tunagrahita sedang, yaitu seseorang dengan kondisi fisik yang sudah terlihat sebagai tunagrahita, mereka mempunyai IQ antara 30 sampai dengan 50. Mereka masih bisa diarahkan dengan perlakuan yang tepat.

3. Tunagrahita berat, yaitu kelompok tunagrahita yang paling rendah tingkat intelegensinya sehingga tidak mampu menerima pendidikan secara akademis. Mereka rata-rata memiliki IQ 30 ke bawah, sehingga dalam kehidupan sehari-hari sangat membutuhkan bantuan orang lain (Pratiwi: 2011).

Masyarakat tunagrahita yang diberdayakan di Lembaga Kesejahteraan Sosial (LKS) Rumah Harapan Mulya adalah tunagrahita kategori ringan dan sedang. Di Lembaga Kesejahteraan Sosial (LKS) Rumah Harapan Mulya, tunagrahita diberdayakan sesuai dengan kondisi dan kemampuan mereka. Tunagrahita ringan akan dibina dan diberdayakan dalam bidang keterampilan yaitu proses pembuatan batik ciprat dan keset kain perca, dan tunagrahita sedang akan dibina dan diberdayakan melalui bidang peternakan. Kegiatan pemberdayaan dilakukan untuk melatih kemampuan bertindak dari para tunagrahita dan melatih mereka supaya dapat hidup dengan mandiri menjalankan aktivitas keseharian mereka.

Warga Desa Karangpatihan mempunyai pekerjaan yang bervariasi seperti desa lain pada umumnya. Berdasarkan data yang diperoleh, mayoritas warganya bekerja sebagai 
buruh tani, petani, pedagang, peternak, dan pengrajin kayu. Terdapat sekitar 50 anggota dari keluarga tunagrahita yang diberdayakan di Lembaga Kesejahteraan Sosial (LKS) Rumah Harapan Mulya. Sebagian besar masyarakat tunagrahita menikah dengan tunagrahita. Hal ini diperoleh melalui penelitian terhadap keluarga tunagrahita yang diberdayakan Lembaga Kesejahteraan Sosial (LKS) Rumah Harapan Mulya.

\section{Peran Lembaga Kesejahteraan Sosial (Lks) Rumah Harapan Mulya Dalam Membentuk Keluarga Sakinah Para Tunagrahita}

Desa Karangpatihan Kecamatan Balong Kabupaten Ponorogo merupakan desa yang sangat luas. Saat melihat peta wilayah, desa ini terbagi menjadi 4 (empat) dusun, yang meliputi Dusun Krajan, Dusun Bibis, Dusun Bendo, dan Dusun Tanggungrejo. Dengan melihat wilayah Desa Karangpatihan yang luas ini, kita dapat memahami adanya karakteristik yang berbeda disetiap masyarakat yang mendiami bagian wilayah desa tersebut. Adanya kemajuan desa terdapat dari keberdayaan masyarakatnya dalam hal yang paling utama yaitu perekonomian masyarakatnya. Dalam memberdayakan masyarakat biasa pada umumnya dilakukan mulai dari pengarahan perbaikan ekonomi keluarga kemudian dilanjutkan dengan pemberdayaan masyarakat setempat untuk meningkatkan pendapatan dan mewujudkan kesejahteraan desa. Namun, masyarakat tunagrahita adalah masyarakat yang memiliki keterbatasan dalam menjalankan kehidupannya. Untuk itu, Lembaga Kesejahteraan Sosial (LKS) Rumah Harapan Mulya menjadi tempat berkumpulnya masyarakat tunagrahita.

Masyarakat tunagrahita juga merupakan masyarakat yang harus memperoleh hak untuk menjalin kehidupan berkeluarga yang layak seperti keluarga normal pada umumnya. Untuk itu, dalam memberdayakan masyarakat tunagrahita harus dimulai dari pendampingan dalam pembentukan keluarga sakinah tunagrahita. Upaya pembentukan keluarga sakinah tunagrahita dilakukan melalui program yang telah disusun oleh Lembaga Kesejahteraan Sosial (LKS) Rumah Harapan Mulya. Hal ini sesuai dengan perwujudan dari maksud dan tujuan keagamaan yang tertera dalam Akta Pendirian Perkumpulan Lembaga Kesejahteraan Sosial Rumah Harapan Mulya No. 08 Tahun 2020.

Rumah tangga menjadi tempat yang tenang bagi setiap anggota keluarga. Mereka merasa nyaman di dalamnya, dan penuh percaya diri ketika berinteraksi dengan keluarga yang lainnya dalam masyarakat. Untuk mewujudkan kenyaman dalam hidup berumah tangga, maka dibutuhkan pasangan suami istri yang saling mendukung (Chadijah: 2018). Terdapat sebuah kerjasama dalam keluarga tunagrahita yang dibina melalui Lembaga Kesejahteraan Sosial (LKS) Rumah Harapan Mulya. Dalam sebuah keluarga tentunya terdapat fungsi dan tanggung jawab dari masing-masing anggota keluarga. Dalam implementasi nyata, keluarga tunagrahita dibina dan diarahkan menuju keluarga sakinah seperti pada umumnya. Pasangan suami istri dari tunagrahita akan dituntun untuk menjalankan peran dan tanggung jawab dalam keluarga. Mereka selalu diingatkan oleh 
masyarakat sekitar dalam hal tanggung jawab mengurus anaknya dan mengarahkan pendidikan yang terbaik anaknya.

Dalam mewujudkan keluarga yang sakinah harus memperhatikan aspek kehidupan manusia yang sesuai dengan ajaran islam, diantaranya yaitu aspek agama, aspek pendidikan, aspek ekonomi, aspek kesehatan dan aspek sosial bernegara (Abbas : 2015). Aspek kehidupan yang pertama adalah aspek agama. Melalui pembinaan para pengurus Lembaga Kesejahteraan Sosial (LKS) Rumah Harapan Mulya, mereka bersosialisasi dengan masyarakat dalam hal kegiatan keagamaan di lingkungannya. Setelah diteliti, anak dari keluarga tunagrahita tidak sepenuhnya mewarisi sifat orang tua, ada diantara mereka yang mampu dibina dengan baik dalam hal agamanya. Bantuan berupa alat sholat untuk mengajak mereka menjalankan ibadah sholat. Aspek kehidupan yang kedua adalah aspek pendidikan. Anak dari pasangan tunagrahita yang mampu belajar akan diarahkan untuk mendapatkan pendidikan sejak usia dini. Pemberian bantuan untuk pendidikan dilakukan melalui Lembaga Kesejahteraan Sosial (LKS) Rumah Harapan Mulya. Aspek kehidupan yang ketiga adalah aspek ekonomi. Dalam menjalani kehidupan sehari-hari, keluarga tunagrahita mereka dibina dan diberdayakan dalam hal perekonomian melalui Lembaga Kesejahteraan Sosial (LKS) Rumah Harapan Mulya. Aspek yang keempat adalah aspek kesehatan. Pemenuhan gizi bagi anak tunagrahita dijaga dengan baik melalui Lembaga Kesejahteraan Sosial (LKS) Rumah Harapan Mulya. Bidan yang bertugas di Polindes Desa Karangpatihan juga ikut membantu dalam berjalannya kehidupan keluarga tunagrahita. Mulai dari perawatan bayi yang baru lahir sampai membina keluarga tunagrahita agar mengikuti Program Keluarga Berencana (KB). Aspek yang kelima adalah aspek sosial bernegara. Keluarga tunagrahita juga manusia yang memiliki hak dan kewajiban yang sama dengan masyarakat pada umumnya. Meskipun harus didampingi dan diarahkan oleh orang lain, keluarga tunagrahita juga aktif dalam kegiatan sosial, seperti kegiatan gotong royong di masyarakat. Dan dalam kehidupan bernegara, masyarakat tunagrahita sebagai warga negara yang taat aturan dan hukum negara. Sebagai contoh pada keluarga tunagrahita di Desa Karangpatihan Kecamatan Balong Kabupaten Ponorogo memiliki dokumen surat pernikahan, sehingga mereka sudah sah secara agama dan hukum. Namun zaman dulu, ada juga yang belum memiliki berkas pernikahan, jadi mereka hanya melakukan nikah siri atau sah secara agama saja.

Berdasarkan hasil penilitian di lapangan dan pengetahuan tentang keluarga sakinah. Keluarga tunagrahita pun mendapati hambatan dan dukungan dalam membangun sebuah keluarga. Faktor penghambat dalam mewujudkan keluarga sakinah salah satunya yaitu kondisi fisik dan psikis penyandang tunagrahita. Kondisi tersebut jelas menjadi faktor penghambat mengingat dalam membangun sebuah keluarga yang sakinah perlu adanya kerjasama yang baik antara suami dan istri dalam mewujudkannya, mulai dari mendidik anak, menjamin kesehatan keluarga, memastikan terpenuhinya kebutuhan keluarga, sampai menjaga hubungan yang baik dengan lingkungan sosial masyarakat. Namun disisi lain 
kondisi tunagrahita tersebut juga bisa menjadi faktor pendukung, keluarga sakinah yang identik dengan ketenangan jelas tercipta pada pasangan tunagrahita. Kondisi psikis pada tunagrahita membuat mereka jarang bersitegang terlalu lama dengan masalah-masalah yang ada, bahkan bisa jadi mereka akan cepat lupa dengan masalah yang dihadapi. Banyak dukungan yang datang dari faktor luar untuk membangun keluarga sakinah dalam keluarga tunagrahita. Dukungan tersebut datang dari kerabat keluarga tunagrahita, masyarakat terdekat, dan perhatian dari pemerintah desa.

Dengan adanya, Lembaga Kesejahteraan Sosial (LKS) Rumah Harapan Mulya mampu melakukan pemberdayaan ekonomi dan sosial masyarakat tunagrahita. Terbentuknya keluarga yang sakinah diantara pasangan tunagrahita menjadi bukti bahwa keluarga tunagrahita mampu bangkit mendayakan dirinya untuk mencukupi kebutuhan keluarganya dan mempertahannkan keutuhan keluarganya. Kesejahteraan keluarga akan mendorong kepada masyarakat yang mampu mendukung pembangunan desa. Penguatan terhadap sistem sosial dilakukan untuk menjaga berlangsungnya kehidupan masyarakat yang sejahtera. Menurut Parson kondisi-kondisi yang menyatakan keberadaan sistem sosial itu agar tetap hidup dan berlangsung dengan baik, maka harus diperhatikan, ada empat fungsi penting yaitu AGIL (A) Adaptation, (G) Goal Attainment, (I) Integration, dan (L) Latensi (Syawaluddin: 2017).

Adaptation (adaptasi), sistem harus menyesuaikan dengan lingkungannya. Dalam hal adaptasi, Lembaga Kesejahteraan Sosial (LKS) Rumah Harapan Mulya menjadi tempat berkumpulnya para tunagrahita untuk saling bersosialisasi dan membentuk kelompok yang siap dibina dan diperdayakan. Mengumpulkan para tunagrahita harus dengan strategi yang tepat. Para pengurus memulai mengajak para tunagrahita dengan berkeliling dari rumah ke rumah secara berkala. Dalam pemberdayakan masyarakat perlu dilakukan pendekatan dan pelatihan yang tepat untuk beradaptasi dengan masyarakat tunagrahita. Pelatihan yang pertama kali dilakukan adalah membuat batik ciprat. Proses pembuatan batik ciprat yang dilakukan melalui Lembaga Kesejahteraan Sosial (LKS) Rumah Harapan Mulya masih dengan dampingan pengurus. Dampingan dari pengurus dimaksudkan untuk memperoleh hasil karya yang lebih rapi. Dan pelatihan pembuatan keset di Lembaga Kesejahteraan Sosial (LKS) Rumah Harapan Mulya sampai tunagrahita dapat mandiri membuat keset di rumah masing-masing. Dan melalui bidang peternakan, keluarga tunagrahita akan diberi bibit dari Pemerintahan Desa Karangpatihan melalui program Lembaga Kesejahteraan Sosial (LKS) Rumah Harapan Mulya. Pemberian bibit dimaksudkan untuk dikembangkan hingga dapat dipanen dan tunagrahita diperbolehkan menjualnya. Bidang peternakan yang dikembangkan melalui Lembaga Kesejahteraan Sosial (LKS) Rumah Harapan Mulya juga mampu memenuhi kebutuhan mereka.

Goal attainment (pencapaian tujuan), sebuah sistem masyarakat harus memiliki suatu arah yang jelas untuk mencapai tujuan utamanya. Lembaga Kesejahteraan Sosial (LKS) 
Rumah Harapan Mulya memiliki tujuan dan cita-cita yang sangat terarah yaitu untuk mensejahterakan kehidupan masyarakat Desa Karangpatihan, khususnya mendorong kemandirian ekonomi keluarga tunagrahita, masyarakat miskin, janda, lansia, anak yatim piatu dan memberdayakan remaja di Desa Karangpatihan.

Integration (integrasi), sebuah sistem haruslah mampu mengatur hubungan antar bagian yang menjadi komponennya. Sistem juga harus mampu mengelola hubungan antara ketiga fungsi penting lainnya. Pemerintah Desa Karangpatihan bermitra dengan Lembaga Kesejahteraan Sosial (LKS) Rumah Harapan Mulya dalam mewujudkan kesejahteraan warganya. Pendekatan yang dilakukan kepada keluarga Tunagrahita dilakukan secara baik dan mengikat, sehingga batin mereka menjadi semangat untuk belajar dan memperbaiki kemandirian ekonomi keluarga. Lembaga Kesejahteraan Sosial (LKS) Rumah Harapan Mulya memiliki potensi yang besar dalam mempertahankan eksistensi batik ciprat, keset, kerajinan sederhana lainnya dan memajukan perekonomian masyarakat, khususnya keluarga tunagrahita. Lembaga Kesejahteraan Sosial (LKS) Rumah Harapan Mulya juga memberikan manfaat yang luas bagi masyarakat Desa Karangpatihan melalui pemberdayaan masyarakat miskin, janda, lansia, anak yatim piatu, dan pemberdayaan remaja.

Latensi, Pemeliharaan pola, sebuah sistem harus saling melengkapi, memelihara dan memperbaiki pola-pola kultural yang menciptakan dan menopang motivasi. Perbaikan yang dilakukan oleh pengurus beserta Pemerintah Desa dilakukan secara terarah dengan melakukan kegiatan monitoring dan evaluasi secara berkala. Sehingga dalam pemberdayaan masyarakat menjadi lebih terarah, dinamis, berkelanjutan dan sangat menarik untuk diikuti oleh warga. Perubahan nama perkumpulan menjadi Lembaga Kesejahteraan Sosial (LKS) Rumah Harapan Mulya menjadikan program dan usaha yang dijalankan semakin luas. Sehingga Lembaga Kesejahteraan Sosial (LKS) Rumah Harapan Mulya ini tidak hanya terfokus untuk menata ekonomi tunagrahita, melainkan juga mulai memberdayakan masyarakat miskin, janda, lansia anak yatim dan remaja.

Dalam pemberdayaan ekonomi yang dilakukan di Lembaga Kesejahteraan Sosial (LKS) Rumah Harapan Mulya, sebagian besar dilakukan oleh perempuan. Dalam pembuatan batik ciprat, hampir keseluruhan pesertanya adalah perempuan. Dalam pembuatan keset juga lebih dominan dilakukan oleh perempuan, namun juga terdapat laki-laki yang membuat keset. Sedangkan peran laki-laki lebih dominan pada pemberdayaan di bidang peternakan. Dalam sebuah keluarga sakinah para tunagrahita, pasangan suami istri saling mendukung dalam hal kelangsungan hidup mereka melalui pembinaan di Lembaga Kesejahteraan Sosial (LKS) Rumah Harapan Mulya. Meskipun sang istri bekerja membuat batik ciprat dan keset, namun sang suami akan mengurus peternakan. Hal ini jelas menjadikan keluarga tunagrahita menjadi harmonis, dan tercukupi kebutuhan keluarganya. Melalui pemenuhan kebutuhan keluarga, pasangan tunagrahita akan mendapatkan ketenangan dalam menjalani kehidupan rumah tangga dan hidup sejahtera. Kebutuhan anak dari pasangan tunagrahita 
akan pendidikan juga terpenuhi melalui pemberdayaan yang dilakukan kepada keluarga mereka. Dan dengan kondisi keterbatasan, membuat pasangan tunagrahita jauh dadi konflik yang serius. Melihat dari perspektif keluarga sakinah dalam agama Islam dan pemberdayaan yang dilakukan sesuai tahapan pemberdayaan dengan dukungan Pemerintah Desa. Maka dari sinilah dapat dipahami bahwa terdapat peran Lembaga Kesejahteraan Sosial (LKS) Rumah Harapan Mulya dalam membentuk keluarga sakinah para tunagrahita.

\section{KESIMPULAN}

Kesimpulan yang dapat diperoleh dari penelitian tentang peran Lembaga Kesejahteraan Sosial (LKS) Rumah Harapan Mulya dalam membentuk kelurga sakinah para tunagrahita adalah sebagai berikut Lembaga Kesejahteraan Sosial (LKS) Rumah Harapan Mulya adalah suatu perkumpulan yang didirikan atas swadaya masyarakat dengan usahausaha yang dilakukan untuk memberdayakan masyarakat tunagrahita, masyarakat miskin, janda, lansia, anak yatim piatu dan remaja demi terwujudnya kesejahteraan mereka. Kegiatan yang ada di Lembaga Kesejahteraan Sosial (LKS) Rumah Harapan Mulya adalah pemberdayaan dibidang keterampilan dan bidang peternakan.

Kondisi objektif masyarakat tunagrahita yang ada di Lembaga Kesejahteraan Sosial (LKS) Rumah Harapan Mulya adalah tunagrahita ringan dan sedang. Dalam bidang keterampilan, tunagrahita ringan diberdayakan dalam membuat batik ciprat dan kerajinan keset kain perca. Sedangkan dalam bidang peternakan, tunagrahita sedang diberdayakan dalam mengelola ternak ayam, kambing dan budidaya ikan lele. Peran Lembaga Kesejahteraan Sosial (LKS) Rumah Harapan Mulya dalam membentuk keluarga sakinah para tunagrahita dapat terwujud melalui pemberdayaan ekonomi dan pembinaan dalam menjalankan tugas dan fungsi setiap anggota keluarga untuk mencapai kehidupan keluarga yang harmonis dan sejahtera.

\section{DAFTAR PUSTAKA}

Abbas, Anwar. "Agama dan Kehidupan Ekonomi Menurut Syafruddin Prawiranegara." AlIqtishad Vol. 5 (Januari 2013). https://www.neliti.com/id/publications/ (diakses 7 Februari 2021).

“Akta Pendirian Perkumpulan Lembaga Kesejahteraan Sosial Rumah Harapan Mulya No. 08," 9 Januari 2020.

Candra, Surya. Penanaman Nilai Karakter Melalui Fungsi Keluarga. Jakarta: Badan Kependudukan dan Keluarga Berencana Nasional, 2017.

Chadijah, Siti. "Karakteristik Keluarga Sakinah dalam Islam.” Rausyan Fikr 14 (2018). http://jurnal.umt.ac.id/index.php/RausyanFikr/article/view/676 (diakses 10 Januari 2021).

Greetz, Clifford. The Interpretation Of Cultures. New York: Basic Books. Inc, 1973. 
Hamid, Hendrawati. Manajemen Pemberdayaan Masyarakat. Makasar: De La Macca, 2018.

Hastuti, Diah R., M. Shaleh Ali, Eymal B. Demmallino, dan Rahmadanih. Ringkasan Kumpulan Mahzab Teori Sosial (Biografi, Sejarah, Teori, dan Kritikan). CV. Nur Lina dan Pustaka Taman Ilmu, 2018.

Kashi, Angriea M. dan Ahmad Zuber. "Upaya Pengetasan Kemiskinan Buruh Genteng Melalui Kegiatan Pemberdayaan Partisipasi Masyarakat.” Jurnal Sosiologi DILEMA 31 (2016). https://jurnal.uns.ac.id/dilema (diakses 15 Februari 2021).

Maikowati, Riski. "Pemberdayaan Masyarakat Melalui Program Non Formal Education di Kampung Blunyah Gede." Jurnal Pemberdayaan Masyarakat: Media Pemikiran dan Dakwah Pembangunan 3 (2019). https://ejournal.uinsuka.ac.id/dakwah/JPMI/article/view/1335 (diakses 10 Februari 2021).

Munawaroh, Rodlotul, dan Refti H. Listyani. "Praktik Sosial Masyarakat Miskin Melalui Model Kerajinan di Desa Karangpatihan Kecamatan Balong Kabupaten Ponorogo." Paradigma 4 (2016). https://www.neliti.com/id/ (diakses 1 Januari 2021).

Nugrahani, Farida. Metodologi Penelitian Kualitatif dalam Penelitian Pendidikan Bahasa. Surakarta: CV. Media, 2014.

Pratiwi, Shinta. Psikologi anak Berkebutuhan Khusus. Semarang: Semarang University Press, 2011.

Raharjo, Santoso T. Isu-Isu Kontemporer Bidang Praktik Pekerja Sosial, Kesejahteraan Sosial, Profesi Pekerjaan Sosial. Sumedang: UNPAD Press, 2015.

Salim, dan Syahrum. Metodologi Penelitian Kualitatif. Bandung: Citrapustaka Media, 2015.

Supriyono, Haris Iskandar, dan Sucahyono. Pendidikan Keluarga dalam Perspektif Masa Kini. Kementerian Pendidikan dan Kebudayaan: Direktorat Jenderal Pendidikan Anak Usia Dini dan Pendidikan Masyarakat, 2015.

Syawaluddin, Muhammad. Teori Sosial Budaya dan Methodenstreit. Palembang: CV. Amanah, 2017.

Umar, Nasaruddin, dan Sugiri Syarief. Fikih Keluarga. Jakarta Selatan: Mitra Abadi Press, 2014.

Wahyuningsih, Sri. Metode Penelitian Studi Kasus (Konsep, Teori Pendekatan Psikologi Komunikasi, dan Contoh Penelitiannya). Madura: UTM Press, 2013. 